\title{
An Exploratory Study on Upgrading by FDI OEMs in China
}

\author{
Tachia Chin \\ Correspondence: Tachia Chin, School of English for International Business, Guangdong University of Foreign \\ Studies, Guangzhou, 510420, P. R. China. E-mail: tachia1231@yahoo.com.sg \\ Received: October 29, 2012 \\ Accepted: November 29, 2012 \\ Online Published: December 13, 2012 \\ doi:10.5539/ibr.v6n1p199 \\ URL: http://dx.doi.org/10.5539/ibr.v6n1p199
}

\begin{abstract}
The paper utilizes the perspectives of global value chain and dynamic capabilities to explore how FDI original equipment manufacturers (OEMs) implement functional upgrading to compete in China's booming market. This research first develops a conceptual framework that identifies the specific capabilities (technological, manufacturing and absorptive capabilities) and leadership style involved in the upgrading trajectory by FDI OEMs, and then employs a multiple-case study with pattern-matching analysis investigating two Singapore-invested OEMs to examine the assumed model. By collecting first-hand timely data, the results have important practical implications for FDI OEMs, as they can help these firms to grow and prosper in the Chinese market.
\end{abstract}

Keywords: manufacturing, capability, upgrading, China, FDI, OEM

\section{Introduction}

Export is commonly viewed as the main driver for China's stunning economic growth over the past three decades (Gao, Murray, Kotabe, \& Lu, 2010). The real engine enabling China to be the global export powerhouse is attributed to a wide range of foreign direct investment (FDI) into this country (Lau \& Bruton, 2008). According to 2011 A.T. Kearney's Confidence Index, China has maintained its position as the most attractive destination of FDI every year since 2002. The increasing inflow of FDI is always responsible for the majority of China's exports (Wielemaker \& Gedajlovic, 2011), promoting China's annual Gross Domestic Product (GDP) and enabling this nation to become the world's second largest economy in 2010.

In terms of the industrial distribution of FDI, about $50 \%$ of FDI into China are found to be pumped into manufacturing sectors since the 90's, particularly into original equipment manufacturing (OEM) (China Statistical Yearbook, 2010). Following the emergence of global value chains (GVC) (Gereffi, Humphrey, \& Sturgeon, 2005), these foreign-invested OEMs have capitalized on China's abundant supply of low-wage labor to manufacture products for developed-country buyers (Gao et al., 2010). However, China has seen annual wage increase and 23\% appreciation of RMB for the last five years, and the trend looks set to continue for the next five years. The low-cost advantages of FDI OEMs are disappearing and export may not be sufficient for these firms to obtain financial success in the future.

Literature shows that the most feasible strategy to enhance economic returns for OEMs is the conduct of functional upgrading: a process to move upward along the GVCs from OEM to original design manufacture (ODM) and eventually to original brand manufacture (OBM) (Morrison, Pietrobelli, \& Rabellotti, 2008; Gereffi et al., 2005). If well-implemented, functional upgrading enables OEM firms to overcome the unequal distribution of profits by engaging in more value-added activities (Humphrey \& Schmitz, 2004). Since China has become the largest consumer market for automobiles, television sets and cell phones, and the second largest for luxury goods during the worldwide recession, its growing domestic market thus symbolizes one silver cloud on the horizon for OEMs to implement this upgrading strategy for value creation.

However, the Chinese mass market demonstrates remarkable heterogeneity and is expected to morph into differentiated and multitiered segments over the next ten years. The China's domestic market is actually a conglomeration of separate regional markets protected by provincial barriers and segmented by a variety of economic and industrial factors (Tse, 2010). Therefore, this multi-market conception inevitably raises problems for foreign investors to compete in China's huge but disordered domestic market. As far as the FDI OEMS, the prominent question is: what are the specific capabilities that these OEMs require corresponding changes to adapt to the dynamic Chinese markets riddled with uncertainties? 
Considering the foregoing arguments, this research incorporates the dynamic capabilities perspective (Barney, 2001; Teece, Pisano, \& Shuen, 1997) into the GVC framework and centers its analysis on the premise that manufacturers must invest to build necessary organizational capabilities to ensure success of functional upgrade along the GVC. Despite numerous studies investigating the value creation of FDI firms in emerging economies ( Li, Wei, \& Liu, 2010; Yang, Wu, \& Lin, 2010; Lin \& Hou, 2010; Liu, Wang, \& Wei, 2009; Horng \& Chen, 2008; Luo \& Tung, 2007), there is a dearth of reliable and timely studies focusing on the key value creation processes of functional upgrading by foreign-invested OEMs in China.

To fill the abovementioned research gap, this paper attempts to use a multiple case study to address the functional upgrading trajectory by FDI OEMs in the Chinese context. Additionally, because functional upgrading involves high risk associated with system-wide changes and there is no guarantee for success, the vision and persistency of the top leadership is vital for pursuing functional upgrading. Hence, we first identify the specific dynamic capabilities and leadership style involved in the upgrading trajectory by FDI OEMs to build a conceptual framework. Then we employ a multiple-case study with a pattern-matching analysis investigating two Singapore-invested OEMs to examine the assumed model.

This study makes three unique contributions. First, this paper presents the evolutionary upgrading strategies of FDI OEMs in China in the face of the new global economy. Further, conducting in-depth interviews with top management in both parent companies in Singapore and their subsidiaries in China, this research responds to a recent call for collecting first-hand timely data to investigate FDI issues in emerging economies (Lau \& Bruton, 2008). Finally, the results offer fresh and critical insights into the practical implications for FDI OEMs to grow and prosper in the Chinese market.

\section{Theoretical Foundations}

\subsection{Functional Upgrading}

Globalization has given many OEM firms in developing countries opportunities to participate in international markets by targeting external markets to gain economics of scale and scope, as well as further technological expertise (Kaplinsky, Readman, \& Memedovic, 2009). This phenomenon is characterized by the concept of the global value chain (GVC) (Giuliani, 2011; Morrison et al., 2008; Gereffi et al., 2005; Humphrey \& Schmitz, 2004). Drawing on the GVC system to coordinate global production and distribution, considerable developing country exporters are able to manufacture a product based on design supplied by an international buyer or just produce a small part of the final product. This GVC approach has provided a primary path for Chinese manufacturers to initiate international business via offering OEM services to large multinational companies (MNEs) and foreign buyers since the reform and opening-up policy over thirty years ago (Li et al., 2010; Yang et al., 2010; Lin \& Hou, 2010).

The GVC view reveals not only a holistic map of the global production network and market, but also a comprehensive and integrated approach explaining industrial development and innovation in emerging countries (Morrison et al., 2008). To exploit the opportunities presented by the GVCs and meanwhile tackle today's hyper-competitive global markets, firms need to innovate or upgrade their capacities for pursuing better financial performance (Kaplinsky \& Morris, 2001; Pietrobelli, 2008; Kaplinsky et al., 2009). Schmitz (2006) questions why the practice of developing country producers only specialize on manufacturing, delegating higher return activities such as the design and marketing functions to their international partners? Following his logic, OEM manufacturers augment per-unit value of products by carrying out functional upgrading to shift their business functions from competing on low-costs production to competing on innovation pertaining to design and marketing activities in GVCs (Chaminade \& Vang, 2008). Kaplinsky and Morris (2001) contend that functional upgrading changes the mix of activities within and between links in the value chain, and could be considered as arrows from production to design and to marketing and branding. In sum, research highlights a hierarchy mechanism of functional upgrading, in which developing country firms transform from original equipment assembling under contract to a global buyer to OEM (producing goods under a buyer's name), to ODM (involving design activities), to OBM (producing own brand products and participating in marketing activities) (Giuliani, 2011; Chaminade \& Vang, 2008; Gereffi et al., 2005; Humphrey \& Schmitz, 2004; Gereffi, 1999).

In China, many OEMs including both local and foreign-invested firms have followed the path of functional upgrading, successfully upgrading to OBM status, such as Taiwan's Acer and China's TCL and Lenovo (Lin \& Hou, 2010). More specifically, they began with OEM, gradually added post-conceptual design services to the manufacturing function, or ODM. Then, armed with design capabilities, they began 
to manufacture finished product to be marketed under their own brands, or OBM. The possession of the competence to implement this OEM-ODM-OBM upgrading by OEMs can be attributed to their collaboration experiences with foreign buyers. Through the cooperation, they learn about international technology, practices and standards from these advanced economy MNEs (Liu et al., 2009; Horng \& Chen, 2008; Luo \& Tung, 2007). This underscores the critical role of learning in functional upgrading and explicitly depicts how the implementation of functional upgrading improves the income of export-oriented OEMs. In fact, many large manufacturers in Asia pacific regions now still provide OEM services to world-class MNEs from developed countries while producing final goods (OBM) to local markets. These OEMs are firms that start from behind in terms of international arenas, but then overcome deficiencies to become global giants themselves, namely, the so-called "Dragon Multinationals" (Mathews, 2006). As a result, more and more OEMs, especially those located in the southeast coastland of China where attracts the most FDI inflows, are inspired by the successful precedents and set to exploit the fast-growing consumer market in China by functional upgrading (Li et al., 2010; Luo \& Tung, 2007).

\subsection{Dynamic Capabilities and Functional Upgrading}

The resource-based view (RBV) states that a firm's competitive advantage is based on the ability to leverage its valuable resources. Linking resources to capabilities, Makadok (2001) defines a capability as an organizationally-embedded, nontransferable firm-specific resource, whose purpose is to improve the productivity of the other resources possessed by the firm. Capabilities are scarce, appropriable and specialized, and are strategic assets that bestow the firm's competitive advantage. Capabilities cannot be bought; rather, they must be built (Lu, Zhou, Bruton, \& Li, 2010; Malik \& Kotabe, 2009). Barney (1991) points out that some capabilities can only be developed over a long period of time. The internal capabilities, combined with external partnerships, are seen as a flexible innovation system (Su, Peng, Shen, \& Xiao, 2012; Lu et al., 2010).

Kaplinsky et al. (2009) indicate that the theory of dynamic capabilities is closely related to the GVC analysis. Originated from RBV, dynamic capabilities are the "abilities to integrate, build, and reconfigure internal and external competences to develop new resources and capabilities" (Teece et al., 1997). Dynamic capabilities thus reflect a firm's ability to achieve new and innovative forms of competitive advantages, reconfiguring its capabilities according to its environmental changes (Su et al., 2012; Malik \& Kotabe, 2009; Sapienza, Autio, George, \& Zahra, 2006; Teece et al., 1997). The theory argues that corporate profitability cannot be sustained by the control over the market (e.g., by using quasi-monopolistic practices), but rather by the development of dynamic capabilities (Kaplinsky et al., 2009).

Nevertheless, how a dynamic capability distinguished from mere capability? According to Sun and Anderson (2010), an organizational capability refers to the set of activities performed by the firm which produce outputs that determine its survival and prosperity within its current strategic setting. Such outputs will not change the strategic direction of the firm. However, a dynamic capability is different, since it reflects a firm's ability to build new capabilities to identify new opportunities and to respond quickly to strategic change (Weerawardena, Mort, Liesch, \& Knight, 2007; Teece, et al. 1997). More specifically, a strategic set of dynamic capabilities does not accrue from the firm, but are built consciously and systematically by the leader's willful decision making and actions.

Functional upgrading is the sequence of acquisitions of internal functional capabilities. Humphrey (2004) points out that the two key elements of upgrading in the GVC are 1) the acquisition of these capabilities, and 2) access to not only general markets, but to particular market channels. Moreover, both the acquisitions and access are dynamic in nature because a shift towards an upper specification/function represents a shift in strategic direction. Following this logic, functional upgrading is considered as a competitive and innovative strategy that requires OEMs to develop bundle of capabilities which help them to overcome the barriers and difficulties crossing different functions, and ultimately increase their economic performance. Taken together, we assume that to ensure successful functional upgrading, firms must possess dynamic capabilities to be able to agilely react to the uncertainties and complexities in today's world.

According to the arguments above, this paper thus focuses on three dynamic capabilities that have been identified to be particularly relevant to the upgrading under the OEM framework in this paper.

\subsubsection{Manufacturing Capabilities}

The level of manufacturing capabilities is a significant facilitator for functional upgrading (Abonyi, 2003). Generally speaking, the degree to which manufacturing capabilities evolve helps determine how an OEM firm performs in the increasingly competitive environment. In the beginning collaborating with large developed 
country MNEs, OEMs typically manufacture simple products and weak in high-end production processes. However, in order to survive, these firms must have a broader range of manufacturing functions at their disposal to meet the dynamic requirements of the outsourcers from mature markets ( $\mathrm{Li}$ et al., 2010; Luo \& Tung, 2007; Yiu, Lau, \& Bruton, 2007; Humphrey, 2004). Hence, the evolution of manufacturing capabilities by OEM firms, ranging from varying product mixes and production volumes to reducing manufacturing process inventories, is expected. For instance, lean manufacturing methods have been widely implemented to increase operation efficiency and manufacturing flexibility (Malik \& Kotabe, 2009; Teece et al., 1997)

\subsubsection{Technological Capabilities}

Technological capabilities pertaining to the intensity of R \& D and innovation are widely viewed as critical strategic assets for generating competitive advantages that determines the success of upgrading by OEMs ( $\mathrm{Su}$ et al., 2012; Giuliani, 2011; Morrison et al., 2008; Yiu et al., 2007). Technological capabilities are not easy to develop or even to imitate because they are embedded in a firm's operation and to a certain extent influence a firm's internal mechanism (Barney, 1991). Extensive empirical results show that firms with higher levels of technological capability are more likely to compete in hyper-competitive international markets (Zou, Chen, Ghauri, 2010; Yiu et al., 2007). By providing manufacturing and assembly services to advanced economy MNEs, OEMs get abundant learning opportunities acquiring advanced technical and R \& D skills to build technological capabilities, including up-to-date technology and the unique capacity to appropriate, adapt, and transform secondary technology (Li et al., 2010; Liu et al., 2009; Luo \& Tung, 2007). This also reflects the dynamic characteristic in building technological capabilities because the development of technological capabilities has to be aligned with the latest need of the fast-changing global markets. It is true that, through cross-border collaboration with developed country technological leaders, some proficient OEM firms gradually build certain level of technological capabilities and thus evolve from suppliers of standard products and services at the bottom of global value chains to become competitors challenging their outsourcers (Mudambi, 2007; Humphrey \& Schmitz, 2004).

\subsubsection{Absorptive Capabilities}

It is recognized that OEM arrangements promote knowledge transfer associated with sophisticated technology, advanced manufacturing know-how or new product development skills between buyers and suppliers along the GVC (Li et al., 2010; Pietrobelli, 2008; Luo \& Tung, 2007). By collaborating with their partners/outsourcers (the world-class leading MNEs), OEM firms can learn a wide range of advanced knowledge that benefits their capabilities development for success in international markets. This kind of competence building is mainly done by apprenticeship and learning-by-doing (Sun \& Anderson, 2010; Weerawardena et al. 2007). "Learning from outsourcers" facilitates OEMs to upgrade from low-end into more value-added statuses along the GVC. Accordingly, absorptive capabilities that represent a firm's ability to utilize external knowledge through the sequential processes of exploratory, transformative, and exploitative learning (Sun \& Anderson, 2010), is of great importance in functional upgrading.

\subsection{Leadership and Functional Upgrading}

Leadership is a strategic construct that reflects the extent to which managers are innovative, proactive, and risk-taking in their behavior and management philosophies (Miller, 1983). It refers to the process, practices, and decision-making activities that the top manager uses to lead a new entry, including such processes as experimenting with promising new technologies or being willing to seize new product opportunities (Kouzes \& Posner, 2007; Northouse, 2007). Leadership is especially important for functional upgrading because the upgrading is a high risk endeavor and there is no guarantee for success. Top managers must have foresights to see the benefits, courage to take the risk, and forbearance and determination to carry through the process. In addition, as noted above, the achievement of functional upgrading requires OEMs to intensify cross-organizational learning from their international partners for building necessary dynamic capabilities. However, due to the asymmetry of power between buyers and vendors, the buyers may not always be willing to provide support for their suppliers' upgrading (Mudambi, 2007; Humphrey \& Schmitz, 2004). In this vein, effective leadership activities that influence a group of individuals to move toward a common goal play a critical role in driving and propelling the whole organization to accomplish functional upgrading.

Incorporating the arguments above, we develop the logic linking the dynamic capability mechanism to the strategy of functional upgrading and draw a conceptual framework as Figure 1. 


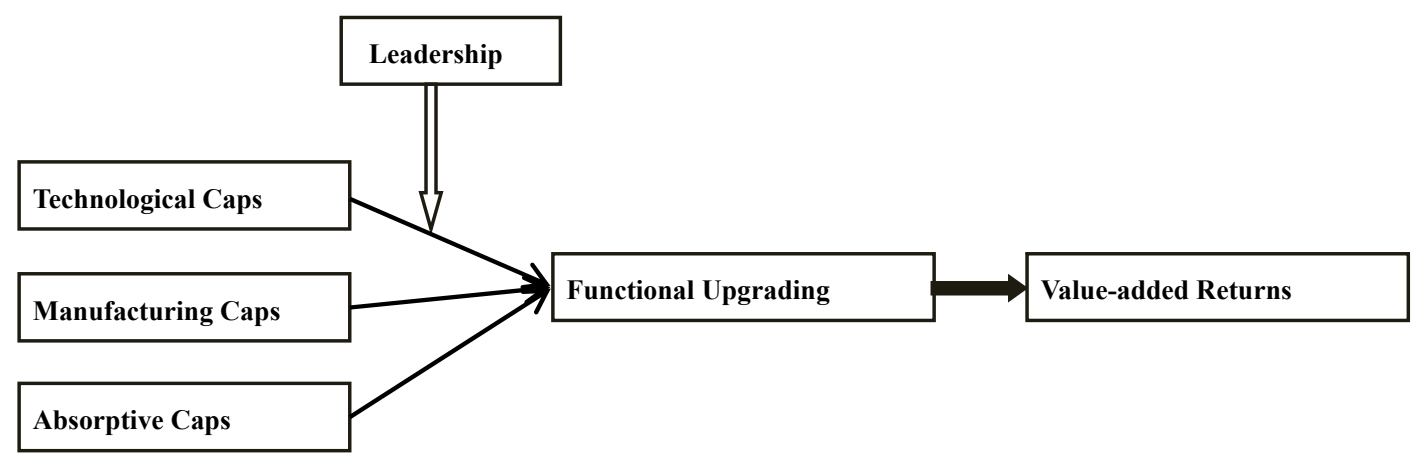

Figure 1. The Conceptual Framework

\section{Methodology}

Due to the qualitative nature of this research topic, case study methodology is appropriate to explore the evolution and interdependencies of firm capabilities in functional upgrading. This paper thus follows case research design using in-depth archival and field data to generate results. According to qualitative methodologists (Yin, 2003; Rialp, Rialp, Urbano, \& Valiant, 2005), a multiple case-based study may serve as a basis for either empirically examining existing theories or establishing new theoretical explanation of new phenomenon being researched. Multiple cases could help to produce replication logic- both literal and theoretical- in which cases are treated as experiments, with each serving to confirm or disconfirm inferences drawn from the others (Yin, 2003). Eisenhardt \& Graebner (2007) also argue that multiple-case research typically yields more robust, generalizable theory than single case. In view of the abovementioned arguments, this paper employs a two-case study to enhance the explanatory power.

In addition, a pattern-matching analysis that enables researchers to capture subtle similarities and differences within cases and associate them with a specific pattern is believed to further reinforce the systematic application of a multiple-case study (Rialp et al., 2005). Therefore, this study also capitalizes on the pattern-matching approach to analyze findings and examine the assumed conceptual framework.

\subsection{Sample Selection}

In case study research, sample selection is one of the most difficult procedures (Yin, 2003) because the research samples have to be specific and representative of all cases. We carefully selected two case firms that are Singapore invested OEMs located in the Guangdong province of China. The choice of Guangdong was motivated by the following considerations. Guangdong is a southern province of Mainland China that hosts nine large cities. Its proximity to Hong Kong has attracted a great amount of foreign firms to set up factories engaging in assembling and manufacturing for the world leading MNEs since the 1980s, which allows Guangdong experiencing stunning economic growth rates for more than two decade. In 2008, the export volume of processing trade in Guangdong province accounted for 64.6 percent of the total export in China.

The choice of Singapore invested OEMs was attributed to the following reasons. Singapore is widely regarded as an important manufacturing hub in Asia with a strong electronics manufacturing sector and emphasis on high technology (Wielemaker \& Gedajlovic, 2011). The manufacturing industry always contributes significantly to the economic growth of Singapore; about a third of the country's annual gross domestic product (GDP). Moreover, since the early 1990s, lots of Singapore manufacturing companies have decided to invest substantial amounts in China, including establishing subsidiary plants or even relocating main production operations to China for obtaining tempting cost advantages (Tsang, 1999). Taken together, Singapore invested OEM firms appear to be suitable samples for this research.

Consistent with Chen (2009), the criteria for selecting the case OEM firms in our study were: (1) the OEM firms located in China are Singapore direct investment companies/subsidiaries; (2) they are subcontracted by large developed country MNEs to manufacture components or parts of final products for them; (3) the names of these OEMs are anonymous in the final products market; (4) they went through the functional upgrading processes; (5) they are presently the leading manufacturers in their respective industries. 
This selection procedure resulted in identification of the following two ventures as our cases: Company A (listed on SGX), headquartered in Singapore, a leading MNE providing a full spectrum of high value-added, integrated turnkey manufacturing services in electronics industry (case \#1), and Company B (listed on SGX), headquartered in Singapore, a famous global company producing and assembling precision-machined components used in automotive and machinery industry (case \#2).

\subsection{Data Sources and Informants}

Data were collected from three sources: (1) face-to-face and phone interviews with the presidents/CEO of the two case firms respectively; (2) interviews with managers of different departments in the same company; (3) secondary sources: the internal documents provided by the companies, information on the companies' websites, the product and firm brochures, as well as newspaper articles, journal articles, research papers, and informal observations.

The interviews were semi-structured and open-ended. Respondents involved were the president/CEO/COO, the manufacturing managers, $\mathrm{R} \& \mathrm{D}$ manager/senior engineers, $\mathrm{CFO}$ /financial manager, and marketing managers.

\subsection{Data Collection Methods}

To obtain robust data, the triangulation approach was exploited at the data collection stage to ensure that different sources were used when gathering data from each firm. The triangulation of data collection, including interview records, internal reports, archival data, and literature, can reveal the true conditions of target enterprises to a maximum extent. To avoid subjectivity, multiple data collection methods were used (Yin, 2003; Eisenhardt \& Craebner, 2007). For instance, the participants were requested to try their best to provide evidence objectively. In the semi-structured interviews, the interviews were conducted by at least three person teams, with one researcher handling the interview questions, while the other two recording notes and observations. For the information items that required exploring at length and in depth, the interviewer would ask the interviewees more follow-up questions. Interviews were tape-recorded at the same time to avoid omitting information and enhance corroborating evidences. To verify the reliability and validity of interviews, the recorded data were processed on the same day they were taped. Also, to resolve any inconsistency, researchers listened to the records and returned to the interviewees repeatedly until the consensuses were reached. If needed, further telephone interviews with relevant people would be conducted.

Since both sample firms are listed companies, a wide range of archival records such as their annual reports and other public statements were used to supplement the interview transcripts. Finally, information and data collected from the diverse sources were prudently cross-checked to ensure the accuracy and reliability.

\section{Empirical Findings}

The findings of our case-based empirical analysis are presented as follows. First, the business profiles of the two case companies are shown in Table 1. Next, each firm's implementation and outcomes of functional upgrading are demonstrated. Finally, the pattern-matching approach is applied to further examine the hypothetical conceptual framework, as displayed in Table 2.

Table 1. Basic business profiles of the two case companies

\begin{tabular}{|c|c|c|}
\hline & Company A & Company B \\
\hline Constitution Year & 1984 & 1981 \\
\hline Listed Year & 2002 listed on Singapore Exchange (SGX) & 2001 listed on SGX \\
\hline Parent Co. /Subsidiaries & $\begin{array}{l}\text { The group is headquartered in Singapore, comprising } \\
\text { about } 40 \text { companies with global clusters of excellence } \\
\text { in South-east Asia, North Asia, America and Europe }\end{array}$ & $\begin{array}{l}\text { The group is headquartered in Singapore, with other } \\
\text { strategic manufacturing locations in Malaysia, China } \\
\text { and Vietnam }\end{array}$ \\
\hline $\begin{array}{l}\text { Current Core Business \& } \\
\text { Main Products }\end{array}$ & $\begin{array}{l}\text { Providing a fully integrated range of electronics } \\
\text { manufacturing services (EMS), OEM, ODM and } \\
\text { e-fulfillment services (EFS) for global leading MNEs } \\
\text { in electronics industry }\end{array}$ & $\begin{array}{l}\text { Providing highly integrated OEM services on } \\
\text { precision-machined components used in automotive } \\
\text { and machinery industry, and precision turned parts in } \\
\text { imaging and printing industry. }\end{array}$ \\
\hline Main Clients & IBM, HP, AVAGO, NCR, & TOYOTA, SONY, HP \\
\hline Revenue in 2011 & $\begin{array}{l}12 \text { billion RMB ( } \$ 1.9 \text { billion) with annual earnings of } \\
786 \text { million } \mathrm{RMB}(\$ 124 \text { million) }\end{array}$ & $\begin{array}{l}409 \text { million RMB ( } \$ 64 \text { million) with annual earnings } \\
\text { of } 19 \text { million RMB ( } \$ 3 \text { million) }\end{array}$ \\
\hline Employees & 14,000 worldwide & 3,000 worldwide \\
\hline
\end{tabular}




\subsection{Case \#1}

Company A, founded in 1984, is currently a well-known contract manufacturer producing a wide range of high-mix, high-value and complex electronic products for global leading MNEs such as IBM and HP. In 1990, Company A first established two plants in Shanghai bonded area in China following the trend of FDI inflow into China in the 1990s, and merely offered OEM services on electronic products to global leading companies at inception. Exploiting a broad range of low-cost advantages including labor, operation, and land rent in the Chinese context, the group augmented its revenue very quickly and thus went public on SGX in 2002. Since then, the group with sufficient funds has put more emphasis on developing technological capabilities, such as engaging in a variety of R \& D activities and building a world-class R \& D team. The technological capabilities development enabled Company A to provide ODM services that can bring better economic returns.

Company A set up several design centers strategically located in Asia, Europe, and America to acquire state of the art technological knowledge. In the pursuit of incorporating design and technology, the group obtained critical know-how and intellectual property with domain expertise in printing, imaging, instrumentation, Radio Frequency communication, networking and data storage used in electronics industry. Company A has continued to exert effort to deepen and diversify technological capabilities. Through leveraging and reconfiguring existing and new technologies, the firm generated dynamic technological capabilities and made significant strides in providing ODM solutions. In 2010, it made outstanding progress on an ODM project with one key storage client, by augmenting this client's tape library system with Company A-designed and developed precision motion control mechanism, robotic arms and system electronics. Moreover, the group continued to improve its customers' point-of sale (POS) products, ranging from updating designs to delivering exceptional combination of reliability and energy efficiency. This enables Company A to be a primary turnkey supplier, as well as strategic partner to manufacture cash registers for IBM. In addition, Company A's technological capabilities are also supported by its effective ERP (Enterprise Resource Planning) system that facilitates information flow and provides an IT infrastructure linking the group with its business partners all over the world in a real-time manner.

As far as manufacturing capabilities, this group keeps strengthening its manufacturing capabilities to meet global leading MNE's latest requirements. The constant evolution and improvement of manufacturing capabilities allows Company A to adapt rapidly to sharp fluctuations and declines in demand in advance economies after the 2008 financial crisis. More specifically, Company A is highly proficient and cost-effective in manufacturing both high-volume and high-mix, low volume products of the highest complexity. To make sure that it had necessary manufacturing capabilities for the upgrade, the group established a comprehensive quality control system to meet the requirements of international standards such as ISO 9001:2008, ISO 13485: 2003 ISO 14001:2004, the ODS (Ozone-Depleting Substances) and RoHS (Restriction of Hazardous Substance).

In terms of absorptive capabilities, Company A always looks upon commercial relationships as mutually beneficial partnerships and encourages a corporate culture of learning from their strategic partners, particularly from those global leading electronic firms. Company A considers the process of transferring knowledge among workers within the supply chain as an important approach and agenda to fledge the group itself. Hence, it paid a lot of attention to activities that could enhance absorptive capabilities, for example, upgrading employees' skills to acquire, assimilate and exploit knowledge on staff training, remuneration structure designing, job allocating, work groups formation, and supervisors' span of control and performance. As a result, Company A uses its great absorptive capabilities to build synergistic relationships with customers and business partners worldwide.

The board committee of Company $\mathrm{A}$ is always managed by top-notch professionals from various streams, including MBA, engineers and financiers. The top management places great premium on talents and innovation, such as attracting experts with special skills to the company's Board, hiring outside professional managers with expertise and experience, and adjusting the salary structure for the core personnel. They frequently host brainstorming sessions with colleagues to motivate a risk-taking spirit and thinking outside the box, which encourages employees to realize their full potential, build strong cohesion, and most importantly, foster creativity. In the transformation process of upgrading from OEM to ODM status, the top management withstood uncertainties and showed high flexibility and adaptability to external changes, which enabled the company to survive the 2008 financial crisis and seize emerging market opportunities. They also show potent strategic desires to upgrade to OBM status in the future. In fact, Company A has tried to sell own-label printers in some shops in the Chinese markets since 2009.

\subsection{Case \#2}

Company B, established in 1981, is now a famous contract manufacturer of precision-machined components and assemblies used in automotive and machinery industry, and a well-known OEM of precision turned parts in 
imaging and printing industry. The company serves diverse market sectors consisting of many global leading MNEs in imaging and printing, consumer electronics, machinery, automotive systems and telecommunications. In 1997, Company B commenced operations in Shanghai, China to engage in OEM business. In 2001, Company B went public on SGX main board after listed on Seadaq board for 3 years. In 2004, to further grab the low-cost advantages and deepen the relationships with its strategic partners, the company set up a factory in Suzhou, China where their major customers of automobile components were located. By doing so, the company was able to initiate ODM projects through close collaboration and communication with global leading firms at that time.

To acquire first tier status as a turnkey supplier of leading MNEs in the GVC, Company B put into a lot of efforts developing technological capabilities for providing total solutions to all customers' machining needs. Emphasizing on customer-oriented technical development, the company established an on-line SPC system which identifies and tracks critical process parameters in productions on a real-time basis. This breakthrough in technological capabilities continuously improves Company B's cross-functional processes arrangements in manufacturing, which allows the company to address the needs of individual customers on service, delivery and quality respectively. In addition, with a sophisticated ERP system, Company B has integrated all activities of its supply chain and thus is able to provide total solutions on Customer Relationship Management (CRM) required in today's ever-changing global marketplace.

In terms of upgrading manufacturing capabilities, Company B has focused on prioritizing processes in production and thus established multi-disciplined manufacturing processes, such as multi-axis CNC turning centers and multi-spindle automatic lathes. The company always ensures that the improvement of manufacturing capabilities is matched with relevant global quality standards, and is certified by ISO/TS 16949, ISO 9002, ISO 14001 and OHSAS 18001.

To upgrade to ODM status and meet the ever-changing needs of the marketplace, Company B has built a potent knowledge base that could constantly encourage organizational members to engage in active learning, system thinking and information sharing with each other, and with cooperative partners throughout GVC activities. The company has operated a comprehensive ITE in-house training program for foreign workers training and certification, which is an officially approved program by the ITE (Institute of technical Education, Singapore) in autonomous maintenance. Through continuous and cross-functional learning in the GVC, the company has developed strong absorptive capabilities that can be employed to recognize external knowledge sources, then assimilate the knowledge acquired, and ultimately integrate it into the existing knowledge bases.

The board committee of Company B has been led by Mr. Tan Chang Chai, a shareholder of the Company since July 1989. Currently, Mr Tan also covers the duties of the group's managing director. Hence, he can be considered as the dominant leader of Company B, playing a key role in setting the overall strategy of the Group. With twenty five years of experience as a chairman/managing director in the die-casting, electroplating, precision turning, precision machining and various assembly businesses, Mr. Tan has led Company B to build and sustain a strong business foundation, which enabled the company to cope well with the economic uncertainties and business volatility such as the 2008 financial crisis and 2010 European debt crisis.

Mr. Tan attached great importance to R\&D, innovation, and most importantly, continuously improvement in operations. He is aggressive, energetic, and resolute with a strong strategic vision and has successfully attracted many talented professionals and experts to work for him. As noted, he was willing to take the risk to initiate the upgrading strategy despite many uncertainties happening in the market place. During the global economic crisis, armed with outstanding manufacturing and technological capabilities, he led Company B to draw on the business slowdown to refine many work processes, such as improving the efficiency of the production and operation structures. In short, he exhibited strong adaptability to the environmental changes and his strategic foresight and ability to seize market opportunities were validated by persuasive evidence. In addition to investing in advanced technology and expanding production capacities during the economic downturn, $\mathrm{Mr}$ Tan also steered the company to undertake high value added businesses with key customers for supporting the customer centric policy. These daring actions boost Company B into a higher level of position as a one-stop solution provider/turnkey supplier of many customers.

\subsection{Pattern-matching Analysis}

In the pattern-matching analysis, the findings were reviewed in greater detail and filtered by the specific capabilities and leadership. This resulted in the patterns reported in Table 3. 
Table 2. Pattern-matching analysis

\begin{tabular}{|c|c|c|}
\hline & Company A & Company B \\
\hline $\begin{array}{l}\text { Technological } \\
\text { capabilities }\end{array}$ & $\begin{array}{l}\text { - Several R \& D centers strategically located in Asia, } \\
\text { Europe, and America } \\
\text { - A high-tech and unique "Point of Sales" system covering } \\
\text { "point of conception" and "point of consumption", } \\
\text { providing a stand-alone service or as part of the value chain } \\
\text { management services to clients } \\
\text { - A supportive and effective ERP system } \\
\text { - Obtaining critical patents and intellectual property used } \\
\text { in electronics industry }\end{array}$ & $\begin{array}{l}\text { - Total solutions to all customers' machining needs } \\
\text { (customer-oriented technological development) } \\
\text { - An on-line SPC system identifies and tracks critical } \\
\text { process parameters in productions on a real-time basis. } \\
\text { - A supportive ERP system integrating all activities } \\
\text { of the supply chain and providing total solutions on } \\
\text { Customer Relationship Management. }\end{array}$ \\
\hline $\begin{array}{l}\text { Manufacturing } \\
\text { Capabilities }\end{array}$ & $\begin{array}{l}\text { - Focus on manufacturing flexibility, highly proficient and } \\
\text { cost-effective in both high-volume and high-mix, low } \\
\text { volume products } \\
\text { - ISO 9001:2008, ISO 13485: } 2003 \text { ISO 14001:2004, } \\
\text { RoHS and the ODS }\end{array}$ & $\begin{array}{l}\text { - Emphasis on prioritizing processes in production, } \\
\text { dealing with multi-disciplined manufacturing } \\
\text { processes simultaneously } \\
\text { - ISO 9001:2002; ISO/TS } 16949 \text { and ISO 14001:2004 } \\
\text { and OHSAS 18001. }\end{array}$ \\
\hline $\begin{array}{l}\text { Absorptive } \\
\text { capabilities }\end{array}$ & $\begin{array}{l}\text { - Encouraging employees to disseminate tacit knowledge } \\
\text { acquired within the supply chain through a wide range of } \\
\text { activities, ranging from staff training, remuneration } \\
\text { structure designing, job allocating, work groups formation, } \\
\text { to supervisors'span of control and performance }\end{array}$ & $\begin{array}{l}\text { - Encouraging active learning between cooperative } \\
\text { partners in GVC activities. } \\
\text { - operating a comprehensive in-house training } \\
\text { program for foreign workers training and certification, } \\
\text { an officially approved program by the ITE in } \\
\text { autonomous maintenance. }\end{array}$ \\
\hline Leadership & $\begin{array}{l}\text { Innovativeness, risk taking, competitive aggressiveness, } \\
\text { empowerment, supportive of the suppliers, emphasizing on cu } \\
\text { sustainable development }\end{array}$ & $\begin{array}{l}\text { visionary, adaptable, persistent, keen on talents, } \\
\text { stomer service and relationships, as well as eco-friendly }\end{array}$ \\
\hline
\end{tabular}

\section{Discussion and Limitations}

\subsection{Discussion}

In accordance with the assumed conceptual framework, the findings examine that technological, manufacturing, and absorptive capabilities are the key dynamic capabilities for FDI OEMs in China to carry out functional upgrading. Furthermore, strong leadership is the central driver for OEM firms to climb the ladder of the GVC, engage in more value-added activities such as ODM and OBM, and eventually earn higher economic returns. In summary, this study illustrates the significance of critical dynamic capabilities in executing the strategy of functional upgrading, and highlights the key role of leadership in guiding the upgrading process. Given that the capabilities are dynamic, management should not wait until they are in place before initiating the upgrade. Instead, they can adopt the approach of building the necessary capabilities from the inception or even in the process of upgrading.

This study made three unique contributions. First, it reveals a holistic picture delineating the upgrading processes of the prevalent FDI OEM model in the Chinese context from a dynamic capabilities perspective. More specifically, this paper explores how Singapore invested OEMs exploit the dynamic capabilities developed via the collaboration with global leading MNEs to implement functional upgrading and then target China's huge domestic market. It indicates that Singapore invested OEMs in China have been successfully transformed from OEM to ODM/OBM modes and thus are able to obtain more economic returns. Second, since in-depth interviews with top management were conducted in both parent companies in Singapore and their subsidiaries in China, this paper responds to a recent call for collecting first-hand timely data to investigate FDI issues in emerging economies (Lau \& Bruton, 2008). Third, on the basis of documenting functional upgrading, this paper presents a context-specific dynamic capability mechanism by foreign-invested OEM firms in China, responding to a recent call for the investigation of dynamic capabilities in a specific context (Weerawardena et al., 2007). Additionally, findings reported here also provides insightful managerial implications for FDI OEMs currently operating in China, facilitating them to further grow and prosper in the Chinese market.

However, compared with Chinese manufacturers that view OEM arrangement with leading firms as a learning springboard to access advanced technological knowledge ( $\mathrm{Li}$ et al., 2010; Luo \& Tung, 2007), Singapore 
invested firms that have already possessed a certain level of sophisticated technology mostly tend to regard OEM collaboration as an effective growth strategy by building contractual partnerships or strategic alliances with large MNEs to secure growth and profits (Kale \& Singh, 2009). Hence, Singapore OEMs may be eager to upgrade to ODM status; however, they usually hesitate to upgrade to the phase of OBM. This is because producing own brand goods is likely to kindle the animosity of the main buyers, or the GVC leaders, towards the suppliers (Morrison et al., 2008). Evidence shows that the OEMs from developing or emerging countries may use collaborative partnership with global leading companies as a means to acquire tacit knowledge and develop key capabilities, thus leapfrogging to compete against their initial outsourcers in international markets directly (Pietrobelli, 2008; Mathews, 2006). Accordingly, most Singapore invested OEMs in China reflects an idiosyncrasy to establish thicker linkages and dense interactions with value chain partners rather than build own brands. Following this logic, it is plausible to claim that foreign- invested OEMs and domestic OEMs in China may view the outsourcing trends concerning functional upgrading along the GVC differently.

\subsection{Limitations and Recommendations}

This exploratory study offers some avenues for future research; however, we acknowledge that it has several limitations. First, in terms of research methodology, a two-case study may not be able to offer sufficient evidence to examine our assumed model. Second, in addition to the three organizational capabilities identified here, there may be others. Third, the levels of importance of the capabilities and interrelationship between the different capabilities are also important to pursue.

Based on the foregoing arguments, it is recommended that future research could conduct a comparative study including firms that did not engage in functional upgrading to provide a more complete picture about the capabilities and leadership being, in fact, the most significant factors in the success of functional upgrading. Moreover, scholars may try to find more vital and relevant capabilities that affect functional upgrading. Future research could also focus on investigating the mechanisms resulting from the interactions of different organizational capabilities, as well as the level of importance of each capability. This effort would help articulate the processes of functional upgrading in a more systematic and extensive manner. Finally, how to achieve the synergy among these capabilities within an enterprise is of great importance, and needs to be further examined.

\section{Acknowledgments}

I gratefully acknowledge the anonymous reviewers for their thoughtful comments and Professor Mao Yunshi for his constructive suggestions on an earlier version of this work. I also acknowledge financial support from the fund of Guangdong University of Foreign Studies (No.12W01).

\section{References}

Abonyi, G. (2003). Challenges of Industrial Restructuring in a Globalizing World: Implications for Small- and Medium-scale Enterprises (SMEs) in Asia. Institute of Southeast Asia Studies, Working Paper: Visiting Researchers Series No. 3(2003).

Barney, J. B. (1991). Firm resources and sustained competitive advantage. Journal of Management, 17(1), 99-120. http://dx.doi.org/10.1177/014920639101700108

Chaminade, C., \& Vang, J. (2008). Globalisation of Knowledge Production and Regional Innovation Policy: Supporting Specialized Hubs in Developing Countries. Research Policy, 37(10), 1684-97. http://dx.doi.org/10.1016/j.respol.2008.08.014

Chen, S. (2009). A transaction cost rationale for private branding and its implications for the choice of domestic vs offshore outsourcing. Journal of International Business Studies, 40, 156-175. http://dx.doi.org/10.1057/palgrave.jibs.8400419

Eisenhardt, K. M., \& Graebner, M. E. (2007). Theory building from cases: Opportunities and challenges. Academy of Management Journal, 50(1), 25-32. http://dx.doi.org/10.5465/AMJ.2007.24160888

Gao, G. Y., Murray, J. Y., Kotabe, M., \& Lu, J. (2010). A "strategy tripod" perspective on export behaviors: Evidence from domestic and foreign firms based in an emerging economy. Journal of International Business Studies, 41(3), 377-396. http://dx.doi.org/10.1057/jibs.2009.27

Gereffi, G. (1999). International trade and industrial upgrading in the apparel commodity chain. Journal of International Economics, 48(1), 37-70. http://dx.doi.org/10.1016/S0022-1996(98)00075-0

Gereffi, G., Humphrey, J., \& Sturgeon, T. J. (2005). The governance of global value chain. Review of International Political Economy, 12(1), 78-104. http://dx.doi.org/10.1080/09692290500049805 
Giuliani, E. (2011). Role of Technological Gatekeepers In The Growth Of Industrial Clusters: Evidence From Chile. Regional Studies, 45(10), 1329-1348. http://dx.doi.org/10.1080/00343404.2011.619973

Horng, C., \& Chen, W. (2008). From contract manufacturing to own brand management: The role of learning and cultural heritage identity. Management and Organization Review, 4(1), 109-133. http://dx.doi.org/10.1111/j.1740-8784.2007.00093.x

Humphrey, J. (2004). Upgrading in global value chains. ILO Policy Integration Department, Working Paper No. 28.

Humphrey, J., \& Schmitz, H. (2004). Globalized Localities: Introduction. In Schmitz, H. (Ed.), Local Enterprises in the Global Economy. Edward Elgar, Cheltenam and Northampton.

Kale, P., \& Singh, H. (2009). Managing strategic alliances: What do we know now, and where do we go from here?. Academy of Management Perspectives, 23(3), 45-62. http://dx.doi.org/10.5465/AMP.2009.43479263

Kaplinsky, R., \& Morris, M. (2001). A Handbook for Value Chain Research. paper prepared for the IDRC. Retrieved from http://www.ids.ac.uk/ids/global/pdfs/VchNov01.pdf.

Kaplinsky, R., Readman, J., \& Memedovic, O. (2009). Upgrading Strategies in Global Furniture Value Chain. United Nations Industrial Development Organization, Vienna.

Kouzes, J. M., \& Posner, B. Z. (2007). The leadership challenge. San Francisco: John Wiley and Sons.

Lau, C. M., \& Bruton, G. D. (2008). FDI in China: What we know and what we need to study next. Academy of Management Perspectives, 22(4), 30-44. http://dx.doi.org/10.5465/AMP.2008.35590352

Li, Y., Wei, Z., \& Liu, Y. (2010). Strategic orientations, knowledge acquisition, and firm performance: The perspective of the vendor in cross-border outsourcing. Journal of Management Studies, 47(8), 1457-1482. http://dx.doi.org/10.1111/j.1467-6486.2010.00949.x

Lin, H., \& Hou, S. (2010). Managerial lessons from the East: An interview with Acer's Stan Shih. Academy of Management Perspectives, 24(4), 6-16. http://dx.doi.org/10.5465/AMP.2010.55206380

Liu, X., Wang, C., \& Wei, Y. (2009). Do local manufacturing firms benefit from transactional linkages with multinational enterprises in China? Journal of International Business Studies, 40, 1113-1130. http://dx.doi.org/10.1057/jibs.2008.97

Lu, Y., Zhou, L., Bruton, G., \& Li, W. (2010). Capabilities as a mediator linking resources and the international performance of entrepreneurial firms in an emerging economy. Journal of International Business Studies, 4l(3), 419-436. http://dx.doi.org/10.1057/jibs.2009.73

Luo, Y., \& Tung, R. L. (2007). International expansion of emerging economy enterprises: A springboard perspective. Journal of International Business Studies, 38(4), 481-498. http://dx.doi.org/10.1057/palgrave.jibs. 8400275

Makadok, R. (2001). Toward a synthesis of the resource-based and dynamic-capability views of rent creation. Strategic Management Journal, 22(5), 387-401. http://dx.doi.org/10.1002/smj.158

Malik, O. R., \& Kotabe, M. (2009). Dynamic capabilities, government policies, and performance in firms from emerging economies: Evidence from India and Pakistan. Journal of Management Studies, 46(3), 421-450. http://dx.doi.org/10.1111/j.1467-6486.2008.00817.x

Matthews, J. A. (2006). Dragon Multinationals. Asia Pacific Journal of Management, 23, 5-27.

Miller, D. (1983). The Correlates of Entrepreneurship in Three Types of Firms. Management Science, 29(7), 770-791. http://dx.doi.org/10.1287/mnsc.29.7.770

Morrison, A., Pietrobelli, C., \& Rabellotti, R. (2008). Global value chains and technological capabilities: A framework to study industrial innovation in developing countries. Oxford Development Studies, 36(1), 39-58. http://dx.doi.org/10.1080/13600810701848144

Mudambi, R. (2007). Managing global offshoring strategies: A case approach. Journal of international Business studies, 38(1), 206-210. http://dx.doi.org/10.1057/palgrave.jibs.8400253

Northouse, P. G. (2007). Leadership: Theory and practice. Thousand Oaks, CA: Sage Publications.

Pietrobelli, C. (2008). Global value chains in the least developed countries of the world: Treats and opportunities for local producers. International Journal of Technological Learning, Innovation and Development, 1(4), 459-481. http://dx.doi.org/10.1504/IJTLID.2008.021964 
Rialp, A., Rialp, J., Urbano, D., \& Valiant, Y. (2005). The Born-Global Phenomenon: A comparative Case Study $\begin{array}{llll}\text { Research. Journal of International Entrepreneurship, } & 3, & \text { 133-171. }\end{array}$ http://dx.doi.org/10.1007/s10843-005-4202-7

Sapienza, H. J., Autio, E., George, G., \& Zahra, S. A. (2006). A capabilities perspective on the effects of early internationalization on firm survival and growth. Academy of Management Review, 31(4), 914-933. http://dx.doi.org/10.5465/AMR.2006.22527465

Schmitz, H. (2006). Learning and earning in global garment and footwear chains. The European Journal of development research, 18(4), 546-571. http://dx.doi.org/10.1080/09578810601070688

Su, Z., Peng, J., Shen, H., \& Xiao, T. (2012). Technological Capability, Marketing Capability, and Firm Performance in Turbulent Conditions. Management and Organization Review. http://dx.doi.org/10.1111/j.1740-8784.2011.00280.x

Sun, P., \& Anderson, M. (2010). An Examination of the Relationship between Absorptive Capacity and Organizational Learning, and a Proposed Integration. International Journal of Management Reviews, 12(2), 130. http://dx.doi.org/10.1111/j.1468-2370.2008.00256.x

Teece, D. J., Pisano, G., \& Shuen, A. (1997). Dynamic Capabilities and Strategic Management. Strategic Management Journal, $18(7)$ 509-533. http://dx.doi.org/10.1002/(SICI)1097-0266(199708)18:7<509::AID-SMJ882>3.0.CO;2-Z

Tsang, E. W. K. (1999). Internationalization as a learning process: Singapore MNCs in China. Academy of Management Executive, 13(1), 91-101.

Tse, E. (2010). The globe: is it too late to enter China? Harvard Business Review, 88(4).

Weerawardena, J., Sullivan Mort, G. M., Liesch, P., \& Knight, G. (2007). Conceptualising Accelerated Internationalization in the Born Global Firm: A Dynamic Capabilities Perspective. Journal of World Business, 42(2), 294-306. http://dx.doi.org/10.1016/j.jwb.2007.04.004

Wielemaker, M., \& Gedajlovic, E. (2011). Governance and capabilities: Asia's entrepreneurial performance and stock of venture forms. Asia Pacific Journal of Management, 28(1), 157-185. http://dx.doi.org/10.1007/s10490-010-9221-9

Yang, C., Wu, Y., \& Lin, H. (2010). Outward investment to China and local innovation of Taiwanese manufacturing firms. The Japanese Economic Review, 61(4), 538-557. http://dx.doi.org/10.1111/j.1468-5876.2009.00498.x

Yin, R. K. (2003). Case study research: Design and methods. California: Sage Publications.

Yiu, D. W., Lau, C., \& Bruton, G. D. (2007). International venturing by emerging economy firms: The effects of firm capabilities, home country networks, and corporate entrepreneurship. Journal of International Business Studies, 38, 519-540. http://dx.doi.org/10.1057/palgrave.jibs.8400278

Zou, H., Chen, X., \& Ghauri, P. (2010). Antecedents and consequences of new venture growth strategy: An empirical study in China. Asia Pacific Journal of Management, 27, 393-421. http://dx.doi.org/10.1007/s10490-009-9157-0

Note

Note 1. Source: Guangdong Statist5ical Yearbooks 2009. 